\section{Works council introductions in Germany: Do they reflect workers' voice?}

Economic and Industrial Democracy 2019, Vol. 40(2) 30I-325 (C) The Author(s) 2016

Article reuse guidelines: sagepub.com/journals-permissions DOI: I0.1 I77/014383IX16645I99

journals.sagepub.com/home/eid

(SAGE

\title{
Michael Oberfichtner
}

University of Erlangen-Nürnberg, Germany; Institute for Employment Research, Germany

\begin{abstract}
While most previous studies focus on the monopoly aspect of works council introductions, this article explores the collective voice face of introductions and investigates workers' decision as an exit-voice consideration. Using a large linked employer-employee dataset from Germany, the present study finds that council introductions are more likely if workers have high plant-specific human capital or earn high wages. These results are consistent with exit-voice considerations as well as with attempts to protect an existing distribution of rents. Redoing the analysis for plants in which the protection of rents against management decisions is less relevant yields similar results supporting a voice interpretation.
\end{abstract}

\section{Keywords}

Exit-voice trade-off, workers' voice, works councils, works council introductions

\section{Introduction}

German works councils have attracted substantial attention from researchers as an institution of industrial democracy that potentially improves wages and working conditions as well as efficiency. Studies on works councils hence investigate their effects on a variety of outcomes such as productivity (e.g. Mueller, 2012; Mueller and Stegmaier, 2014), wages (Addison et al., 2010), profits (Mueller, 2011), employment growth (Jirjahn, 2010), employment stability (Hirsch et al., 2010; Pfeifer, 2011a), apprenticeship training (Kriechel et al., 2014), job satisfaction (Grund and Schmitt, 2013), or look at several of these outcomes within one study (Addison et al., 2001; Hübler and Jirjahn, 2003; Jirjahn, 2014; Pfeifer, 2011b; Wigboldus et al., 2014). ${ }^{1}$ Compared with this vast literature on existing councils (for surveys see Addison, 2009; Jirjahn, 2011), relatively few studies

\footnotetext{
Corresponding author:

Michael Oberfichtner, University of Erlangen-Nürnberg, Lange Gasse20, 90403 Nürnberg, Germany.

Email: michael.oberfichtner@fau.de
} 
explicitly look at workers' decision and motives to introduce a works council, which is the focus of the present investigation.

Works councils have substantial power via extensive co-determination rights, which workers can use in two, not mutually exclusive ways. They can influence the distribution of an existing surplus between workers and owners or they can increase the total surplus of the firm. In a different context, Freeman and Medoff (1979) labelled this the two faces of unionism: monopoly and collective voice. While the first description implies that unions, and works councils, focus on the redistribution of rents, the second takes a more positive stance as it implies that they increase efficiency, for example by improving communication between workers and management as modelled by Freeman and Lazear (1995), and that they might even benefit owners.

While the literature on existing works councils pays similar attention to both of these two faces, previous studies on the workers' decision to introduce a council place greater emphasis on the monopoly face. More specifically, studies on works council introductions often focus on the relationship between a plant's economic situation and the likelihood of an introduction. Introductions in good times are then interpreted as offensive, i.e. attempts to change the distribution of rents in the workers' favour, whereas introductions in bad times are interpreted as defensive, i.e. attempts to preserve an existing distribution of rents.

This article takes a different starting point and asks whether works council introductions reflect workers' voice. I look at workers' decision regarding whether or not to introduce a council as an exit--voice consideration along Hirschman's (1970) reasoning, where introducing a council is a form of voice and quitting is a form of exit. Using a large linked employer-employee dataset, I provide empirical evidence on the role of workers' wages, tenure, as well as the local labour market situation as determinants of works council introductions. While previous studies largely neglect these factors, I document that workers with high tenure and workers earning high wages are more likely to introduce a council. These findings are consistent with an underlying exit-voice trade-off.

The structure of the article is as follows. First, I briefly describe the institutional background and review the previous literature on works council introductions. Second, I consider workers' decisions as an exit-voice consideration to derive testable hypotheses that should hold when workers trade off introducing a council against leaving their employer. Next, I present my empirical analysis. The final section concludes.

\section{Institutional background and previous literature on works council introductions}

The parallel existence of several forms of worker representation is a major characteristic of Germany's system of industrial relations. While unions represent workers at the sector level and firms can choose whether to bargain with them, works councils represent workers at the plant level, and a council is mandatory if workers decide to introduce one. To give some numbers, Ellguth and Kohaut (2011) report that $10 \%$ of all eligible plants had a council in 2010. The legal basis of works councils is set in the Works Constitution Act (WCA), the latest major revision of which came into force in July 2001. A more detailed account of the institutional framework can be found in Addison (2009).

Workers are entitled to introduce a works council in plants with at least five permanent workers with voting rights, three of whom must be eligible to run for office. Workers 
have voting rights if they are at least 18 years old, and they can run for office if they have additionally been employed in the plant for at least six months. The WCA aims to provide a simple procedure and to prevent any influences from the management. Council introductions run as follows. First, at least three workers (or a union represented in the plant) have to call a meeting of the workforce. At this meeting an electoral board is determined by majority vote. This board calls the election, runs it and announces the results. If the meeting fails or is not held, the labour court appoints a board. For plants with at most 50 workers there is a streamlined procedure, which also can be applied in plants with 51-100 workers if workers and the employer agree to do so. Apart from that, management must not influence the introduction. Interfering with the election of a council is even punishable with up to one year in prison or a fine. As a further means of protecting initiators of councils against oppressive measures, workers who call the meeting of the workforce, are on the electoral board, or run for office enjoy special employment protection as do councillors.

On the empirical side, Schlömer-Laufen and Kay (2012) qualitatively investigate 10 successful works council introductions and give an opportunity to compare legal setting to practice. They find that it takes typically between three and six months to introduce a council, supporting that introducing a council is simple. Looking at management behaviour, councillors in no case report that management tried to prevent the introduction, though management was critical in some plants. Occasionally, management even seems to support council introductions, which is also in line with Mohrenweiser et al. (2012). However, the picture is somewhat flawed as both studies can only look at successful introductions and there is no systematic evidence on failed attempts to introduce councils. $^{2}$

To sum up, the legal framework aims to enable workers to introduce a council when they wish to do so and to protect them from adverse consequences. And, the empirical evidence indicates that these protective measures are successful in enabling workers to introduce works councils. Therefore, council introductions are an opportunity to learn about workers' motives when introducing a council. This has drawn some attention to the workers' decision to introduce councils.

Table 1 displays the empirical results on the determinants of works council introductions. ${ }^{3}$ While the results on plant size, collective bargaining status and the legal form of plants are quite consistent, the results regarding plants' economic circumstances are less clear cut. The existing evidence on plants' profits probably favours a defensive interpretation, though the evidence is mixed and limited. Furthermore, there is some evidence of a positive relationship between organizational changes and council introductions, though this relationship is not found in all studies. Similarly, the results regarding employment growth are ambiguous. Finally, workforce characteristics are mostly included as control variables and, again, no clear picture emerges from the previous results.

\section{Works council introductions as an exit-voice consideration}

According to Hirschman (1970), members of an organization trade off voice against exit in declining organizations, read when they are dissatisfied with their situation. If workers differ in their mobility, as argued by Freeman and Medoff (1984), less mobile workers will be more inclined to opt for voice, here introduce a works council. Previous research 
Table I. Previous literature on the determinants of works council introductions.

Study Findings

Addison et al. (2003)

Plant characteristics: Introductions more likely in large plants, plants with collective bargaining agreement (CBA), branch plants, and in limited companies.

Plant's economic situation: No relationship with good business situation.

Workforce characteristics: No relationship with the shares of bluecollar, part-time, female and shift workers

Addison et al. (2013) Plant characteristics: Introductions more likely in large plants, plants with CBA and profit sharing; introductions less likely in plants in individual ownership; no relationship with branch plant status. Plant's economic situation: No relationship with expectation of increasing sales.

Workforce characteristics: Introductions more likely in plants with high shares of female and fixed-term workers; introductions less likely in plants with a high share of part-time workers; no relationship with share of skilled workers.

Beckmann et al. (2010) Plant characteristics: Introductions more likely in plants with CBA, branch plants and in limited companies; no additional effect of plant size, when controlling for log(value added).

Plant's economic situation: Introductions more likely in plants with high log(value added); no clear results for expected employment growth; no relationship with in- and outsourcing activities.

Workforce characteristics: No relationship with shares of apprentices and blue-collar, fixed-term and female workers.

Dilger (2003)

Plant characteristics: Introductions more likely in plants with further training activities, working groups and a firm-level CBA; introductions less likely in plants with process innovations; no relationship with plant size, sector-level CBA and payment schemes.

Plant's economic situation: No relationship with turnover per capita. Workforce characteristics: No relationship with the workforce composition (details are not reported).

Dilger's (2003) model as a whole has no significant explanatory power.

Jirjahn (2009) Plant characteristics: Introductions more likely in large plants, branch plants, plants with profit sharing, group piece rates, research activities and in limited companies; no relationship with CBA. Plant's economic situation: Introductions more likely in plants with very poor sales situation and plants with declining employment; introductions less likely in plants with expansive management strategy.

Workforce characteristics: Introductions more likely in plants with a high share of skilled blue-collar workers; introductions less likely in plants with high shares of apprentices and part-time workers; no relationship with total share of blue-collar workers and share of university graduates. 
Table I. (Continued)

\begin{tabular}{ll}
\hline Study & Findings \\
\hline Jirjahn and & Plant characteristics: Introductions more likely in large plants, plants \\
Mohrenweiser (2013) & with CBA, branch plants and in limited companies; introductions \\
& less likely in plants with active owners. \\
& Plant's economic situation: Introductions more likely after \\
& employment reductions; no relationship with organizational \\
& changes, poor employment outlook and relative employment \\
& change. \\
& Workforce characteristics: No relationship with the shares of skilled, \\
& female and part-time workers and with the churning rate in the \\
& first half of the year. \\
& Plant characteristics: Introductions more likely in large plants, plants \\
& with CBA, branch plants, in limited companies and in plants with \\
& employee share ownership; no effect of profit sharing. \\
& Plant's economic situation: Introductions less likely in plants with \\
& good profit situation; no relationship with expectation of increasing \\
& sales and employment. \\
& Workforce characteristics: Introductions less likely in plants with a \\
Kraft and Lang (2008) & high share of blue-collar workers; no relationship with shares of \\
& female and part-time workers. \\
& Plant characteristics: Introductions more likely in large plants, plants \\
& with CBA, branch plants and in limited companies. \\
& Plant's economic situation: Introductions more likely after \\
& organizational changes and in plants with low employment growth \\
relative to sector; no further relationship with employment growth & and bad business situation. \\
& Workforce characteristics: Introductions less likely in plants with \\
a high share of part-time workers (not controlling for share of \\
female workers); no relationship with shares of skilled workers and \\
apprentices.
\end{tabular}

Notes: Listed relationships are significant at the $10 \%$ level. Dilger (2003) uses the NIFA Panel. Jirjahn (2009) uses the Hannover Firm Panel. The other studies use the IAB Establishment Panel. Mohrenweiser et al. (20I2) use the IfM Bonn Works Council Survey in addition to the IAB Establishment Panel.

for West Germany shows marked mobility differences between demographic groups. For instance, Boockmann and Steffes (2010) document that employment of older workers is more stable and that workers with a higher qualification level are more likely to change employers, but less likely to go into non-employment. Hirsch and Schnabel (2012) further document that women are less likely to change employer than men, but more likely to go into non-employment.

These differences suggest differences in workers' demand for a voice mechanism, and hence the workforce composition could affect the likelihood of works council introductions. For example, highly qualified workers should be less likely to introduce a council as they are more mobile. However, they might also be able to make better use of such an institution and might find the administrative burdens less demanding, which would work in 
the opposite direction, and we therefore do not obtain a clear prediction. For other groups, the interplay of incentives, mobility and institutions blurs predictions. For instance, women are typically less attached to the labour force than men, which also should make them less inclined to introduce a works council. Still, works councils have strong rights with regard to social matters and working time arrangements, which could be more important for women as they typically take on more responsibilities in their families.

Therefore, I do not focus on demographic characteristics in the empirical analysis, though it will be important to control for such differences as the composition of the workforce may influence the likelihood of works council introductions. Rather, I use Hirschman's (1970) exit-voice reasoning to generate hypotheses that relate workers' decision to introduce a council with their plant-specific human capital, the labour market situation and the wage level. These hypotheses should hold if workers' decision is based on an exit-voice trade-off and introductions reflect workers' voice. First, workers lose their plant-specific human capital if they quit. Hence, I hypothesize that workers with high plant-specific human capital will be more likely to introduce a council, as quitting is more costly for them. To measure specific human capital, I use the median of the workers' tenure, which gives the time over which workers have accumulated such capital.

Topel (1991) points out several caveats about using tenure to proxy specific human capital at the individual level. He argues that high tenure in a cross-sectional setting may rather reflect a high, time-constant match or job quality than specific capital. In a setting with on-the-job search, high job quality would make it unlikely that workers receive a superior job offer, and tenure, in such a setting, would at least partly reflect job quality. Topel (1991) shows that using within-match variation in tenure to estimate the effect of tenure mitigates such concerns. Paralleling this, I will present specifications that identify the effect of tenure on the likelihood of works council introductions from within-plant variation in tenure. Further, Topel (1991) argues that tenure captures both work experience in general as well as experience in a specific plant. To alleviate such concerns, I control for workers' age, which captures workers' potential general work experience since I also control for workers' education. Taking these concerns into account, Farber (1999: 2470) concludes that tenure is still an attractive measure of specific capital, as '[w]orkers with more tenure are likely to have more specific capital than workers with less tenure'. In the empirical analysis, I will however use information on plant-specific training, which is rather limited in the data, as an alternative measure of specific human capital.

From a monopoly perspective, high tenure could reflect that workers are for some reason in a relatively beneficial position, which would rather point towards defensive introductions. Further, if long tenure is driven by a lack of (better) outside offers, this could also indicate that workers are in a relatively weak bargaining position. However, specific capital could also foster offensive introductions. The investments to build up such capital, say training costs, are sunk creating a rent, which is to be distributed. From this perspective, council introductions could be an attempt by workers to obtain a larger share of these rents. Therefore, the results on specific human capital are not informative on the question of rent-seeking versus rent-protection.

Second, quitting is less feasible if there are few job market alternatives. Thus, workers with fewer alternatives should be more inclined to introduce a council. To measure 
workers' job market alternatives, I use the unemployment rate in the plant's district assuming that workers are regionally immobile. As an alternative measure, I use occupational unemployment rates assuming that workers are immobile in this dimension. From a monopoly point of view, one would expect offensive introductions in times of low unemployment and defensive introductions in times of high unemployment.

Third, a new job should yield a similar or higher wage. If the wage level at a plant is high, such a job is more difficult to find. Therefore, workers in plants with high wage levels should introduce a council with higher probability. To measure the wage level, I use the median of the full-time workers' wages when controlling for the occupation and education structure as well as for other wage-related characteristics. From a monopoly perspective, high wages should lead to more defensive introductions, but not foster offensive introductions unless one assumes that ceteris paribus higher rents remain available in plants already paying high wages than in those paying low wages.

None of these hypotheses has been tested before, though some studies touch upon them. Kraft and Lang (2008) match introducing and not-introducing plants and observe higher wages and fewer quits in introducing plants, but they do not match on workers' qualifications. Mohrenweiser et al. (2012) include wages above the level specified in collective bargaining agreements as a control variable, a rather vague measure for the wage level, and do not find a significant association with council introductions. Gralla and Kraft (2012) observe that the share of dismissals is on average lower in plants that will introduce a works council than in plants that will not do so. Importantly, none of these studies accounts for workforce characteristics in detail since they do not have direct information on workers. To give an example, none of the studies takes into account differences in workers' education as well as age and sex. Using a linked employer-employee dataset allows me to overcome this and control in much more detail for worker characteristics and test the three hypotheses more directly and more thoroughly.

The three hypotheses derived from workers' exit-voice trade-off are also in line with defensive works council introductions. When we observe these patterns one hence may ask whether this reflects rent-protection or workers' voice. To investigate this more closely, I will also look at plants in which it is less relevant for workers to protect themselves against management, which promises some insights into which plants drive the results. Finding the same results for the restricted sample would support an underlying exit-voice trade-off since such a pattern shows that the results are not driven by the plants in which rent-protection is most relevant. If the hypotheses are, in contrast, confirmed in the complete sample, but not when restricting the sample, this would point towards a defensive interpretation. I will therefore report results for subsamples based on the likely relevance of wage reductions, layoffs and the profit situation.

Concerning wage cuts, the German regime of industrial relations provides an opportunity to get some additional insights. Collective bargaining agreements provide minimum working conditions, while firms may voluntarily offer better conditions, e.g. pay higher wages, as studied by Jung and Schnabel (2011). Compared to plants that are either not subject to a collective agreement or pay wages above the level specified in an agreement, it is more difficult to reduce wages in plants that strictly pay wages specified in a binding agreement. Thus, the rent-protection argument is less relevant in this sample of plants. ${ }^{4}$ 
Looking at workers' perceived employment security is more difficult since no direct measure is available. Still, workers should obviously be concerned about employment security when managers expect employment reductions and I will therefore use managers' expectations on employment changes to identify plants in which workers should have particularly strong concerns regarding layoffs. While we cannot be sure that workers do not worry about individual dismissals in other plants, the rent-protection argument is still less relevant for the remaining plants than for the complete sample. Using managers' expectations, I create three subsamples. First, I drop observations from plants that expect decreasing employment in the next year. Second, I drop all observations from plants that ever expect decreasing employment in the next year. Third, I take a more long-run perspective and drop all plants that ever expect lower employment in five years' time.

More generally speaking, rent-protection should be most relevant in plants that are economically in trouble. Therefore, I also use the available information on the plants' business situation to identify plants in which rent-protection should be less relevant. First, I drop plants that ever had an unsatisfactory profit situation in the previous year during the sample period. Second, I drop plants that ever expect business volume to decrease.

\section{Data and descriptive evidence}

In the empirical analysis, I use the cross-sectional model of the LIAB for the years 2001 to 2010, i.e. the Linked Employer-Employee Dataset of the Institute for Employment Research (IAB) of the German Federal Employment Agency (Alda et al., 2005 provide further details). The dataset links administrative data on workers with the IAB Establishment Panel, of which I additionally use earlier and later waves. This allows me to control in detail for both worker and plant characteristics.

Looking at the plant side, the IAB Establishment Panel is a random sample of about 16,000 German plants. The sample is drawn according to the principles of optimal stratification from the administrative register of plants that employ at least one worker liable to social security. Strata are defined over plant sizes and industries and large plants are oversampled. The response rates of plants that are repeatedly interviewed exceed $80 \%$, making the dataset well suited to follow plants over time. The survey provides information on the plant's works council status, the number of workers, its collective bargaining status, profit situation and industry affiliation, among others. Using this information, I drop all observations that cannot introduce a council since they already have one or have fewer than five workers. I also exclude not-for-profit plants from the analysis, i.e. plants from administrative sectors, plants in public ownership and plants measuring their business volume by budget.

On the worker side, the dataset is based on the Employee History, which is drawn from the integrated notification procedure for health, pension and unemployment insurances. The notification procedure requires employers to report information on all workers covered by the social security system. These notifications are compulsory and misreporting is prohibited. As a consequence, information is available for all workers 
liable to social security in plants that are covered by the Establishment Panel. Although, among others, civil servants and family workers are not included, about $80 \%$ of all employed individuals are part of the Employee History. The data include information on workers' daily wage, tenure, age, sex, occupation and education. ${ }^{5}$

To reduce measurement error in works council introductions and ensure that I observe actual introductions of new councils, I identify a plant as introducing a council in $t$ if it neither has a council in $t-1$ nor in $t$, but reports having a council in $t+1$ and $t+2$. Unless plants misreport twice in a row, this coding avoids measurement error in the introduction variable. Paralleling, I identify a plant as not introducing a council in $t$ if it reports having no council from $t-1$ through $t+1$ and is also observed in $t+2$ ensuring that the minimum observation period is equally long for both groups. This procedure leaves me with 29,190 observations of 7,598 plants, 237 of which reflect council introductions between 2001 and 2011. The numbers imply that the average probability of an introduction is $0.8 \%$. The dataset is not only unbalanced by missing information and panel attrition, but also by the construction of the dependent variable since a plant cannot be in the sample directly after an introduction.

Table 2 presents some descriptive statistics. According to the human capital hypothesis, one would expect that workers of introducing plants have longer tenure. However, the data show that the average median tenure is 0.5 years higher in plants without introduction. Turning to the labour market situation, the unemployment rate is on average 0.5 percentage points lower for introducing plants, again not supporting the hypothesis. This difference is however insignificant. In contrast, the evidence on the wage level is in line with the hypothesis as median real wages are on average $23 \log$ points, or $€ 15.5$ per day, higher in introducing plants. However, both types of plants differ substantially and also significantly in many other dimensions. For example, introducing plants are larger, 17\% have at least 200 workers compared to $3 \%$ of the not-introducing plants, and they are also more often subject to a collective agreement, $59 \%$ compared to $38 \%$.

\section{Econometric analysis}

To investigate the determinants of works council introductions, I fit binary response models, where an introduction is coded as a success. Given the low average probability of introductions, I consider them as rare events and thus use complementary log-log models throughout the analysis (for a brief overview see Cameron and Trivedi, 2005: 466-467). To begin with, I investigate only the hypotheses about plant-specific human capital and the labour market situation, but leave out the wage hypothesis since wages are potentially affected by both. Next, I turn to the wage hypothesis. Afterwards, I report the results when using alternative measures of specific human capital and workers' labour market alternatives, when restricting the sample to plants in which rent-protection is less relevant and from the robustness checks.

As a starting point, I use a pooled maximum likelihood approach. I regress council introductions between $t$ and $t+l$ on workers' median tenure (tenure $\left.{ }_{i t}\right)$, the unemployment rate at the plant's district as of 30 June of $t\left(U R_{i t}\right)$, the workforce composition and the plant's business situation $\left(x_{i t}\right)$ as well as further control variables $\left(z_{i t}\right)$. Thus, the model is: 
Table 2. Descriptive statistics.

\begin{tabular}{|c|c|c|c|c|c|}
\hline \multirow[t]{2}{*}{ Explanatory variables } & \multicolumn{2}{|c|}{ No introduction } & \multicolumn{2}{|c|}{ Introduction } & \multirow{2}{*}{$\begin{array}{l}p \text {-value for equality } \\
\text { of means }\end{array}$} \\
\hline & Mean & SD & Mean & SD & \\
\hline Median tenure in years & 6.301 & 4.031 & 5.781 & 3.929 & .044 \\
\hline Unemployment rate in per cent & 12.76 & 5.61 & 12.26 & 5.44 & .164 \\
\hline $\begin{array}{l}\text { Log(median real wage in } 2005 \\
\text { Euros) }\end{array}$ & 4.088 & 0.373 & 4.316 & 0.341 & $<.001$ \\
\hline Median real wage in 2005 Euros & 63.78 & 23.93 & 79.28 & 27.20 & $<.001$ \\
\hline $\begin{array}{l}\text { Collective bargaining at the } \\
\text { sector level (d) }\end{array}$ & 0.340 & 0.474 & $0.5 \mathrm{II}$ & 0.501 & $<.001$ \\
\hline $\begin{array}{l}\text { Collective bargaining at the firm } \\
\text { level (d) }\end{array}$ & 0.038 & 0.192 & 0.080 & 0.272 & .001 \\
\hline Plant with limited liability (d) & 0.588 & 0.492 & 0.899 & 0.302 & $<.001$ \\
\hline Branch plant (d) & 0.076 & 0.265 & 0.422 & 0.495 & $<.001$ \\
\hline Foreign ownership (d) & 0.024 & 0.152 & 0.110 & 0.313 & $<.001$ \\
\hline Plant in rural area (d) & 0.354 & 0.478 & 0.295 & 0.457 & .060 \\
\hline Plant in East Germany (d) & 0.469 & 0.499 & 0.405 & 0.492 & .049 \\
\hline 5-20 workers (d) & 0.562 & 0.496 & 0.224 & 0.418 & $<.001$ \\
\hline $21-100$ workers $(d)$ & 0.363 & 0.481 & 0.464 & 0.500 & .001 \\
\hline $101-199$ workers (d) & 0.047 & 0.213 & 0.148 & 0.356 & $<.001$ \\
\hline 200 or more workers (d) & 0.027 & 0.162 & 0.165 & 0.372 & $<.001$ \\
\hline Organizational shock (d) & 0.036 & 0.187 & 0.101 & 0.302 & $<.001$ \\
\hline $\begin{array}{l}\text { Good profit situation (previous } \\
\text { business year, } d \text { ) }\end{array}$ & 0.373 & 0.484 & 0.451 & 0.499 & .013 \\
\hline Relative employment growth & 0.028 & 0.307 & 0.064 & 0.256 & .034 \\
\hline Median age in years & 41.00 & 7.12 & 40.56 & 5.88 & .257 \\
\hline Share of part-time workers & 0.207 & 0.223 & 0.230 & 0.273 & .195 \\
\hline Share of female workers & 0.413 & 0.300 & 0.415 & 0.290 & .915 \\
\hline Share of apprentices & 0.063 & 0.098 & 0.042 & 0.064 & $<.001$ \\
\hline Share of highly qualified workers & 0.070 & 0.158 & 0.093 & 0.166 & .032 \\
\hline Share of qualified workers & 0.785 & 0.230 & 0.756 & 0.218 & .041 \\
\hline $\begin{array}{l}\text { Share of workers in manual } \\
\text { occupations }\end{array}$ & 0.489 & 0.364 & 0.397 & 0.370 & .000 \\
\hline $\begin{array}{l}\text { Share of workers in business } \\
\text { occupations }\end{array}$ & 0.287 & 0.291 & 0.367 & 0.350 & .001 \\
\hline Observations & 28,953 & & 237 & & \\
\hline
\end{tabular}

Notes: The unemployment rate is measured at the district level. The median wage refers to full-time workers only. (d) denotes dummy variables and employment growth is relative to employment in the previous year. Highly qualified workers have obtained a college or university degree, qualified workers have completed Abitur and/or an apprenticeship, the remaining, low qualified workers are used as reference group. Occupational structure is measured with an aggregated form of Blossfeld (1985) and service occupations are the reference group. Organizational shocks encompass the closure, relocation or separation of a plant or parts of it or the integration of a plant or a plant unit. The dataset used is the LIAB, cross-sectional model, 200I-20I0. 


$$
P\left(\text { introduction }_{i t}=1\right)=F\left(\beta_{1} \text { tenure }_{i t}+\beta_{2} U R_{i t}+x_{i t}{ }^{\prime} \theta+z_{i t}{ }^{\prime} \gamma\right)
$$

where $F(\cdot)$ is the cumulative distribution function of the extreme value distribution. ${ }^{6}$

Since we have seen above that the composition of the workforce may affect the likelihood of council introductions, it will be important to control for such differences in the econometric analysis. Therefore, $x_{i t}$ encompasses the workers' median age, the shares of part-time workers, female workers, apprentices, qualified and highly qualified workers as well as workers in manual and business occupations. To capture the plant's economic situation, which according to the previous literature also affects the likelihood of council introductions, $x_{i t}$ furthermore includes a dummy variable indicating a good or very good profit situation in the previous business year and the employment growth in the previous year. Since the institutional setting and previous studies suggest a higher likelihood of council introductions in plants with a collective agreement and in large plants, $z_{i t}$ includes dummy variables for collective bargaining agreements at the firm and at the sector level and three plant size dummies. Further, $z_{i t}$ contains dummies for plants with limited liability, subsidiary plants and organizational shocks at a plant, which have previously been found to relate to works council introductions. Finally, $z_{i t}$ includes dummies for plants in foreign ownership, five plant age groups, nine industries, location in East Germany and in rural areas as well as year dummies to control for plant heterogeneity and possible time trends. ${ }^{7}$

Given the vast evidence on the effect of works councils on variables like workers' tenure, the profit situation or wages for that matter, one may wonder how the effect of councils on these variables affects the estimation. Importantly, introductions take place between $t$ and $t+1$, while all explanatory variables are measured as of $t$ or earlier. Hence, the covariates are measured before a works council is present. As long as councils do not have substantial effects before their introduction, later effects of council are unproblematic as the plants are no longer in the sample when these effects come into play. Taking this into account, re-introductions of works councils remain potentially problematic as in such cases characteristics before the introduction of a new council could be affected by the previously existing council. To address this, I will exclude from the analysis plants that ever reported having a works council before as a robustness check.

The first column of Table 3 presents the average partial effects (APE) using this specification. Council introductions are 0.7 percentage points more likely in plants that are covered by a collective agreement at the sector level than in plants not covered by a collective agreement, ceteris paribus. Looking at agreements at the firm level, the estimated effect is somewhat larger, but estimated imprecisely. Furthermore, the likelihood of introductions is between 0.5 (for plants with $21-100$ workers) and 3.4 percentage points (plants with 200 or more workers) higher in larger plants than in plants with at most 20 workers. Further, workers in branch plants and in plants with limited liability are more inclined to introduce councils. These results are in line with the institutional framework and the previous literature. The coefficients of all of these variables are statistically significant at the $1 \%$ level. 
Table 3. Average partial effects on the probability of a works council introduction.

\begin{tabular}{|c|c|c|c|c|}
\hline \multirow[t]{2}{*}{ Explanatory variables } & \multicolumn{2}{|c|}{$\begin{array}{l}\text { Pooled maximum } \\
\text { likelihood }\end{array}$} & \multicolumn{2}{|c|}{$\begin{array}{l}\text { Correlated random } \\
\text { effects }\end{array}$} \\
\hline & APE & SE & APE & SE \\
\hline Median tenure & $0.0005^{* *}$ & 0.0002 & $0.0014 * * *$ & 0.0003 \\
\hline Unemployment rate & $<0.0001$ & 0.0002 & 0.0001 & 0.0004 \\
\hline Collective bargaining at the sector level (d) & $0.0069 * * *$ & 0.0015 & $0.0068 * * *$ & 0.0015 \\
\hline Collective bargaining at the firm level (d) & $0.0103^{* * *}$ & 0.0041 & $0.0106 * * *$ & 0.0041 \\
\hline Plant with limited liability (d) & $0.0074 * * *$ & 0.0011 & $0.007 \mid * * *$ & 0.0011 \\
\hline Branch plant (d) & $0.0180 * * *$ & 0.0029 & $0.0177 * * *$ & 0.0029 \\
\hline Plant in foreign ownership (d) & 0.0031 & 0.0025 & 0.0030 & 0.0025 \\
\hline Plant located in rural area $(\mathrm{d})$ & -0.0004 & 0.0012 & -0.0002 & 0.0012 \\
\hline Plant located in East Germany (d) & -0.0013 & 0.0020 & -0.0014 & 0.0020 \\
\hline Plant with $21-100$ workers (d) & $0.0045 * * *$ & 0.0010 & $0.0049 * * *$ & 0.0011 \\
\hline Plant with $10 \mathrm{I}-199$ workers (d) & $0.0147^{* * *}$ & 0.0035 & $0.0151 * * *$ & 0.0035 \\
\hline Plant with 200 or more workers (d) & $0.0340 * * *$ & 0.0065 & $0.0344 * * *$ & 0.0067 \\
\hline Organizational shock (d) & $0.0053 * *$ & 0.0027 & $0.0055^{* *}$ & 0.0027 \\
\hline $\begin{array}{l}\text { Good profit situation (previous business } \\
\text { year, d) }\end{array}$ & 0.0010 & 0.0011 & $0.0022 *$ & 0.0012 \\
\hline Relative employment growth & $0.0008 *$ & 0.0004 & 0.0007 & 0.0009 \\
\hline Median age & $<0.0001$ & 0.0001 & $0.0004 *$ & 0.0002 \\
\hline Share of part-time workers & $0.005 \mathrm{I} * *$ & 0.0026 & $0.0103 *$ & 0.0056 \\
\hline Share of female workers & -0.0016 & 0.0029 & 0.0057 & 0.0083 \\
\hline Share of apprentices & -0.0099 & 0.0076 & $0.0326 * *$ & 0.0153 \\
\hline Share of highly qualified workers & $0.0094 * *$ & 0.0040 & $0.0265 * * *$ & 0.0096 \\
\hline Share of qualified workers & 0.0037 & 0.0032 & $0.0142 * *$ & 0.0061 \\
\hline Share of workers in manual occupations & 0.0004 & 0.0027 & $0.0205^{*}$ & 0.0110 \\
\hline Share of workers in business occupations & 0.0031 & 0.0028 & -0.0007 & 0.0065 \\
\hline Observations & 29,190 & & 29,190 & \\
\hline Works council introductions & 237 & & 237 & \\
\hline
\end{tabular}

Notes: Complementary log-log models are fitted and the dependent variable is an indicator that takes the value of $\mathrm{I}$ if a council is introduced in the next year. Five plant age, nine industry and nine year dummies are further control variables. The plant age dummies are coded in five year steps with one final category capturing an age of 25 years or higher. Plants aged less than five years are used as reference group. The correlated random effects model includes the plant averages of workers' median tenure and the other workforce characteristics, the unemployment rate, the profit situation and the employment growth. Standard errors of average partial effects are calculated using the delta method. The dataset used is the LIAB, cross-sectional model, 200I-2010. */**/*** denote statistical significance of the estimated coefficient at the $10 \% / 5 \% / 1 \%$ level using standard errors clustered at the plant level.

Turning to the hypotheses to be tested, I find that the probability of a council introduction is 0.05 percentage points higher if the median of the workers' tenure is one year higher. Thus, a one standard deviation rise in workers' tenure raises the likelihood of an introduction by about one-quarter of the average probability. The coefficient is also statistically significant at the $5 \%$ level. Further, the results show no relationship between the 
local unemployment rate and the likelihood of works council introductions. However, these results are obtained relying on variation within as well as between plants and may hence reflect unobserved heterogeneity.

To address time-invariant unobserved heterogeneity, I apply a correlated random effects approach and include the plant-level averages of the main variables of interest and other characteristics that have substantial variation within plants, $\bar{x}_{i}$, in the model. $\overline{x_{i}}$ comprises the plant-level averages of workers' median tenure, the other workforce characteristics, the unemployment rate and the business situation. This approach goes back to Mundlak (1978) and allows for an unobserved time-constant effect that is correlated with the means of these variables. The model now reads:

$$
P\left(\text { introduction }_{i t}=1\right)=F\left(\beta_{1 a} \text { tenure }_{i t}+\beta_{2 a} U R_{i t}+x_{i t}^{\prime} \theta_{a}+z_{i t}{ }^{\prime} \gamma_{a}+\bar{x}_{i}^{\prime} \xi\right)
$$

and the estimated parameters can be used to compute average partial effects. One can investigate the presence of unobserved heterogeneity of the described form by testing the significance of $\hat{\xi}$. This approach closely resembles the correlated random effects probit model discussed in Wooldridge (2010: 615-617). ${ }^{8}$

The second column of Table 3 presents the results from this correlated random effects model. ${ }^{9}$ The estimated effect of an increase in the median tenure is larger and amounts to a 0.14 percentage point increase of the likelihood of council introductions in response to a one year increase of the median tenure within a plant and is statistically significant at the $1 \%$ level. As before, the local unemployment rate is not related to works council introductions.

Regarding the plant's economic situation, I find that workers are 0.6 percentage points more likely to introduce a works council after organizational shocks, which is significant at the $5 \%$ level. Further, I find weak evidence that the probability of a council introduction is higher when the profit situation is good, controlling for the average situation of the plant, though this relation is only significant at the $10 \%$ level. Employment growth appears to have no effect on the likelihood of works council introductions.

I further find that the workforce composition influences the likelihood of council introductions, again based on within-plant variation. Council introductions are more likely when the shares of qualified and highly qualified workers are large. Further, workers are more likely to introduce a council when the share of apprentices is high. While these results are significant at least at the $5 \%$ level, the positive relationships of introductions with workers' median age and the shares of part-time workers and workers in manual occupations are only significant at the $10 \%$ level.

As the coefficients $\hat{\xi}$ are jointly significant (with $p=.0015$ ), I stay with the correlated random effects model to study the wage hypothesis and add the log of the median of the workers' wages as an explanatory variable. The results are given in Table 4, first column. Controlling for wages does not change the results outlined above, mitigating concerns about multicollinearity between wages, tenure and local unemployment. ${ }^{10}$ In line with the hypothesis, high wages are positively related with the likelihood of council introductions, implying that a $1 \%$ increase of the median wage raises the probability by 
Table 4. Average partial effects on the probability of a works council introduction, controlling for the wage level.

\begin{tabular}{|c|c|c|c|c|}
\hline \multirow[t]{2}{*}{ Explanatory variables } & \multicolumn{2}{|c|}{$\begin{array}{l}\text { Correlated random } \\
\text { effects w/o average } \\
\text { wage }\end{array}$} & \multicolumn{2}{|c|}{$\begin{array}{l}\text { Correlated random } \\
\text { effects with average } \\
\text { wage }\end{array}$} \\
\hline & APE & SE & APE & SE \\
\hline Log(median wage) & $0.0116 * * *$ & 0.0022 & -0.0037 & 0.0039 \\
\hline Average log(median wage) & & & $0.0164 * * *$ & 0.0045 \\
\hline Median tenure & $0.0013^{* * *}$ & 0.0003 & $0.0014^{* * * *}$ & 0.0003 \\
\hline Unemployment rate & 0.0003 & 0.0004 & 0.0003 & 0.0005 \\
\hline $\begin{array}{l}\text { Collective bargaining at the sector } \\
\text { level (d) }\end{array}$ & $0.0067 * * * *$ & 0.0015 & $0.0067^{* * * *}$ & 0.0015 \\
\hline $\begin{array}{l}\text { Collective bargaining at the firm } \\
\text { level (d) }\end{array}$ & $0.0104 * * *$ & 0.0041 & $0.0104^{* * *}$ & 0.0041 \\
\hline Plant with limited liability (d) & $0.0068 * * *$ & 0.0011 & $0.0067 * * *$ & 0.0011 \\
\hline Branch plant (d) & $0.0154 * * *$ & 0.0026 & $0.0151 * * *$ & 0.0026 \\
\hline Plant in foreign ownership (d) & 0.0008 & 0.0022 & 0.0008 & 0.0022 \\
\hline Plant located in rural area (d) & 0.0003 & 0.0012 & 0.0003 & 0.0012 \\
\hline Plant located in East Germany (d) & 0.0014 & 0.0022 & 0.0017 & 0.0022 \\
\hline Plant with $21-100$ workers (d) & $0.0048 * * *$ & 0.0011 & $0.0048^{* * *}$ & 0.0010 \\
\hline Plant with $10 \mathrm{I}-199$ workers (d) & $0.0145^{* * *}$ & 0.0034 & $0.0144 * * *$ & 0.0034 \\
\hline Plant with 200 or more workers (d) & $0.0322 * * *$ & 0.0062 & $0.0317^{* * * *}$ & 0.0062 \\
\hline Organizational shock (d) & $0.0058 * * *$ & 0.0027 & $0.0057^{* * * *}$ & 0.0027 \\
\hline $\begin{array}{l}\text { Good profit situation (previous } \\
\text { business year, } d \text { ) }\end{array}$ & $0.0022 *$ & 0.0012 & $0.0021 *$ & 0.0012 \\
\hline Relative employment growth & 0.0007 & 0.0008 & 0.0006 & 0.0007 \\
\hline Median age & 0.0004 & 0.0002 & 0.0004 & 0.0002 \\
\hline Share of part-time workers & 0.0074 & 0.0062 & $0.0123 * *$ & 0.0063 \\
\hline Share of female workers & 0.0072 & 0.0085 & 0.0052 & 0.0085 \\
\hline Share of apprentices & $0.0316 * *$ & 0.0157 & $0.0334 * *$ & 0.0158 \\
\hline Share of highly qualified workers & $0.0259 * *$ & 0.0102 & $0.0276 * * * *$ & 0.0105 \\
\hline Share of qualified workers & $0.0147 * *$ & 0.0064 & $0.0151 * *$ & 0.0065 \\
\hline $\begin{array}{l}\text { Share of workers in manual } \\
\text { occupations }\end{array}$ & $0.0193^{*}$ & 0.0116 & $0.0215^{* *}$ & 0.0114 \\
\hline $\begin{array}{l}\text { Share of workers in business } \\
\text { occupations }\end{array}$ & -0.0045 & 0.0072 & 0.0006 & 0.0070 \\
\hline Observations & 29,190 & & 29,190 & \\
\hline Works council introductions & 237 & & 237 & \\
\hline
\end{tabular}

Notes: See Table 3.

0.012 percentage points. The effect is comparatively small but still significant at the $1 \%$ level. As before, the coefficients $\hat{\xi}$ are jointly significant $(p=.0003)$.

While the wage effect is identified by variation between plants and within plants in the first column of Table 4, I additionally include the average wage as an explanatory 
Table 5. Alternative measures of workers' specific human capital and labour market alternatives.

\begin{tabular}{|c|c|c|c|c|}
\hline \multirow[t]{2}{*}{ Explanatory variables } & \multicolumn{2}{|c|}{$\begin{array}{l}\text { Correlated random } \\
\text { effects w/o average } \\
\text { wage }\end{array}$} & \multicolumn{2}{|c|}{$\begin{array}{l}\text { Correlated random } \\
\text { effects with average } \\
\text { wage }\end{array}$} \\
\hline & APE & SE & APE & SE \\
\hline \multicolumn{5}{|c|}{ A: Plant-specific training activities } \\
\hline Plant-specific training & $0.0023 *$ & 0.0012 & $0.0023 *$ & 0.0012 \\
\hline Log(median wage) & $0.0113^{* * * *}$ & 0.0021 & -0.0045 & 0.0047 \\
\hline Average log(median wage) & & & $0.0168 * * *$ & 0.0051 \\
\hline Median tenure & $0.0013 * * *$ & 0.0004 & $0.0013^{* * * *}$ & 0.0004 \\
\hline Unemployment rate & -0.0002 & 0.0004 & -0.0001 & 0.0004 \\
\hline Observations & 27,398 & & 27,398 & \\
\hline Works council introductions & 215 & & 215 & \\
\hline \multicolumn{5}{|c|}{ B: Occupational unemployment rates } \\
\hline Log(median wage) & $0.0117 * * *$ & 0.0022 & -0.0037 & 0.0039 \\
\hline Average log(median wage) & & & $0.0166 * * *$ & 0.0045 \\
\hline Median tenure & $0.0013^{* * * *}$ & 0.0003 & $0.0013^{* * * *}$ & 0.0003 \\
\hline Occupational unemployment rate & $<0.0001$ & 0.0003 & 0.0001 & 0.0003 \\
\hline Observations & 29,189 & & 29,189 & \\
\hline Works council introductions & 237 & & 237 & \\
\hline
\end{tabular}

Notes: The specifications used are the correlated random effects models with and without average wages as in Table 4. In Panel A, I additionally include a dummy for plants which provided specific training the last time this item was asked. In Panel B, the local unemployment rate is replaced by an occupational unemployment rate. Further, see Table 3.

variable in the second column to address unobserved plant heterogeneity that is correlated with the average wage level. Thereby, the wage effect is now identified only by within-plant changes. Relying only on within-plant variation, the effect of wages is statistically insignificant and the point estimate is even negative, though it is practically zero. Hence, between-plant differences in wages drive the positive relation between wages and the likelihood of works council introductions. The coefficients $\hat{\xi}$ are again jointly significant $(p=.0001)$.

Table 5 reports the results using a dummy variable for plant-specific training and occupational unemployment rates as alternative measures of workers' plant-specific human capital and their labour market alternatives. ${ }^{11}$ According to Panel A, the probability of an introduction is about 0.2 percentage points higher in plants that provide specific training, supporting a positive relationship between specific capital and council introductions. However, the relationship is only significant at the $10 \%$ level. In Panel B, I replace the local unemployment rate by occupational unemployment rates. Using this alternative measure, I again do not find a link between workers' labour market alternatives and the likelihood of council introductions.

So far, we have found that workers with high tenure and workers earning high wages are more likely to introduce a works council, where the relationship with wages is driven 
by differences between plants and not by changes within plants. This is compatible with underlying exit-voice considerations since wage differences between employers should determine the attractiveness of workers' outside options. Controlling for the average wage level removes such inter-plant differences from the wage effect. Finally, no link shows up between workers' labour market alternatives and council introductions.

As outlined above, the tested hypotheses are consistent with an exit-voice reasoning as well as with rent-protection. Therefore, I will next turn to the restricted samples of plants in which defensive introductions are less relevant. ${ }^{12}$ Table 6 reports the results from the analysis, replicating Table 4. For all subsamples the main findings are

Table 6. Sample restricted to plants for which rent-protection is less relevant.

\begin{tabular}{|c|c|c|c|c|}
\hline \multirow[t]{2}{*}{ Explanatory variables } & \multicolumn{2}{|c|}{$\begin{array}{l}\text { Correlated random } \\
\text { effects w/o average } \\
\text { wage }\end{array}$} & \multicolumn{2}{|c|}{$\begin{array}{l}\text { Correlated random } \\
\text { effects with average } \\
\text { wage }\end{array}$} \\
\hline & APE & SE & APE & SE \\
\hline \multicolumn{5}{|c|}{ A: Plants strictly paying according to collective agreement } \\
\hline Log(median wage) & $0.0273 * * *$ & 0.0066 & 0.0108 & 0.0146 \\
\hline Average log(median wage) & & & 0.0172 & 0.0153 \\
\hline Median tenure & $0.0022^{* *}$ & 0.0010 & $0.0023^{* *}$ & 0.0010 \\
\hline Unemployment rate & 0.0005 & 0.0012 & 0.0006 & 0.0013 \\
\hline Observations & 5,265 & & 5,265 & \\
\hline Works council introductions & 69 & & 69 & \\
\hline \multicolumn{5}{|c|}{ B: Without plants that expect negative employment growth } \\
\hline Log(median wage) & $0.0113 * * *$ & 0.0023 & -0.0074 & 0.0050 \\
\hline Average log(median wage) & & & $0.0199 * * *$ & 0.0056 \\
\hline Median tenure & $0.0010 * * *$ & 0.0003 & $0.0010 * * *$ & 0.0003 \\
\hline Unemployment rate & 0.0003 & 0.0005 & 0.0004 & 0.0005 \\
\hline Observations & 25,923 & & 25,923 & \\
\hline Works council introductions & 209 & & 209 & \\
\hline \multicolumn{5}{|c|}{ C: Without plants that ever expect negative employment growth } \\
\hline Log(median wage) & $0.0156 * * *$ & 0.0030 & -0.0075 & 0.0074 \\
\hline Average log(median wage) & & & $0.0244 * * *$ & 0.0081 \\
\hline Median tenure & $0.0013 * * *$ & 0.0005 & $0.0014 * * *$ & 0.0005 \\
\hline Unemployment rate & 0.0007 & 0.0007 & 0.0008 & 0.0007 \\
\hline Observations & $|7,83|$ & & $|7,83|$ & \\
\hline Works council introductions & 194 & & 194 & \\
\hline \multicolumn{5}{|c|}{ D: Without plants that ever expect lower employment in five years' time } \\
\hline Log(median wage) & $0.0134 * * *$ & 0.0024 & -0.0021 & 0.0048 \\
\hline Average log(median wage) & & & $0.0165 * * *$ & 0.0053 \\
\hline Median tenure & $0.0014 * * *$ & 0.0004 & $0.0014 * * *$ & 0.0004 \\
\hline Unemployment rate & 0.0002 & 0.0005 & 0.0002 & 0.0005 \\
\hline Observations & 23,146 & & 23,146 & \\
\hline Works council introductions & 207 & & 207 & \\
\hline
\end{tabular}


Table 6. (Continued)

\begin{tabular}{|c|c|c|c|c|}
\hline \multirow[t]{2}{*}{ Explanatory variables } & \multicolumn{2}{|c|}{$\begin{array}{l}\text { Correlated random } \\
\text { effects w/o average } \\
\text { wage }\end{array}$} & \multicolumn{2}{|c|}{$\begin{array}{l}\text { Correlated random } \\
\text { effects with average } \\
\text { wage }\end{array}$} \\
\hline & APE & SE & APE & SE \\
\hline \multicolumn{5}{|c|}{ E: Without plants that ever have an unsatisfactory profit situation } \\
\hline Log(median wage) & $0.0135^{* * * *}$ & 0.0029 & -0.0068 & 0.0073 \\
\hline Average log(median wage) & & & $0.0215^{* * *}$ & 0.0078 \\
\hline Median tenure & $0.0019 * * *$ & 0.0005 & $0.0019 * * *$ & 0.0005 \\
\hline Unemployment rate & 0.0007 & 0.0006 & 0.0007 & 0.0006 \\
\hline Observations & 20,465 & & 20,465 & \\
\hline Works council introductions & 204 & & 204 & \\
\hline \multicolumn{5}{|c|}{ F: Without plants that ever expect a decrease in business volume } \\
\hline Log(median wage) & $0.0246 * * *$ & 0.0047 & -0.0093 & 0.0108 \\
\hline Average log(median wage) & & & $0.0358 * * *$ & 0.0119 \\
\hline Median tenure & $0.0019 * *$ & 0.0008 & $0.0022 * * *$ & 0.0008 \\
\hline Unemployment rate & 0.0010 & 0.0010 & 0.0011 & 0.0010 \\
\hline Observations & 10,407 & & 10,407 & \\
\hline Works council introductions & 164 & & 164 & \\
\hline
\end{tabular}

Notes: See Table 3. The specifications used are the correlated random effects models with and without average wages as in Table 4.

confirmed showing that the results are not driven by the plants in which rent-protection is most relevant. This makes it unlikely that the results are only driven by attempts to influence the distribution of rents. Rather, it suggests an exit-voice trade-off underlying workers' decision whether or not to introduce a works council.

To check the robustness of the results, I address two possible objections to the validity of the empirical analysis. First, the descriptive statistics show substantial and significant differences between plants with council introductions and plants without council introductions in many dimensions and one could argue that a simple regression approach is insufficient to address this. To deal with this, I redo the analysis with a more homogeneous sample and match exactly on sector, plant size, plant age, collective bargaining status and location in West or East Germany. Second, works councils are a dynamic phenomenon and introducing plants might have had a works council before. In such plants high tenure and wages could rather be consequences of a previously existing council than causes of an introduction. Thus, I exclude all plants from the sample that have ever reported having a council using all available data back until 1993. Table 7 gives the average partial effects from these robustness checks confirming the previous findings. While the size of the partial effects differs somewhat across the subsamples and in comparison with the main specification, the results are quite similar when considering the effects relative to the average probabilities of council introductions. 
Table 7. Robustness checks.

\begin{tabular}{|c|c|c|c|c|}
\hline \multirow[t]{2}{*}{ Explanatory variables } & \multicolumn{2}{|c|}{$\begin{array}{l}\text { Correlated random } \\
\text { effects w/o average wage }\end{array}$} & \multicolumn{2}{|c|}{$\begin{array}{l}\text { Correlated random } \\
\text { effects with average wage }\end{array}$} \\
\hline & APE & SE & APE & SE \\
\hline \multicolumn{5}{|l|}{ A: Matched sample } \\
\hline Log(median wage) & $0.0203^{* * * *}$ & 0.0053 & -0.0096 & 0.0091 \\
\hline Average log(median wage) & & & $0.0320 * * *$ & 0.0107 \\
\hline Median tenure & $0.0027 * * *$ & 0.0009 & $0.0027 * * *$ & 0.0008 \\
\hline Unemployment rate & -0.0007 & 0.0010 & -0.0006 & 0.0010 \\
\hline Observations & 11,803 & & 11,803 & \\
\hline Works council introductions & 237 & & 237 & \\
\hline \multicolumn{5}{|c|}{ B: Without plants that ever reported having a works council before } \\
\hline Log(median wage) & $0.0074 * * * *$ & 0.0019 & -0.0026 & 0.0032 \\
\hline Average log(median wage) & & & $0.0108 * * *$ & 0.0037 \\
\hline Median tenure & $0.0014 * * *$ & 0.0003 & $0.0013 * * *$ & 0.0003 \\
\hline Unemployment rate & -0.0001 & 0.0004 & -0.0001 & 0.0004 \\
\hline Observations & 27,688 & & 27,688 & \\
\hline Works council introductions & 164 & & 164 & \\
\hline
\end{tabular}

Notes: See Table 3. The specifications used are the correlated random effects models with and without average wages as in Table 4. The sample on Panel A is matched exactly on sector, plant size, plant age, collective bargaining status and location in West or East Germany.

\section{Conclusions}

This study explores the collective voice face of works council introductions by investigating workers' decision to introduce a council as an exit-voice consideration. If workers trade off introducing a council against quitting, they should be more inclined to introduce a council if they have high plant-specific human capital, have few labour market alternatives or earn high wages. In the main analysis, I use workers' median tenure, the local unemployment rate and the median wage at the plant to measure these characteristics. While I do not find any relationship between the labour market situation and council introductions, the results show that workers with high plant-specific human capital and workers earning high wages are more likely to introduce a works council. These results also hold when defining labour markets by occupations and when using information on plant-specific training to measure workers' specific human capital. The wage result however only holds when looking at differences between plants, but not when focusing on wage changes within plants.

The findings on workers' tenure and wages are consistent with an exit-voice consideration as well as with the notion that workers introduce a council to protect an existing distribution of rents. Therefore, I separately look at plants in which rent-protection is less relevant. The patterns in these plants are very similar, suggesting that council introductions do reflect workers trading off introducing a council against quitting. Notwithstanding, the support of an exit-voice consideration underlying the introduction of works councils 
is of an indirect nature and the results do not rule out that workers in some cases elect a council for other reasons. Therefore, this study rather adds an additional perspective on works council introductions than it rules out other explanations.

Contrasting the results with previous research on works council introductions, the estimates confirm findings on plant size, collective bargaining, legal form and branch plant status. The results on the economic situation are similar to Mohrenweiser et al. (2012), who also observe a positive relationship between organizational shocks and introductions, though I find weak evidence that workers are more likely to introduce a works council when a plant's profit situation is better than on average in that plant.

Looking at the research on existing councils, it is interesting to see that two aspects that are often seen as effects of works councils already show up before their introduction: higher wages and longer tenure (see the surveys in Addison, 2009; Jirjahn, 2011). From the monopoly point of view, this supports the notion that councils rather act defensively than offensively. This is also in line with the possible defensive interpretation of this study's results. However, it may well be that older councils were introduced with different intentions or that councils change their behaviour over time and it hence remains unclear whether such a generalization is valid. Furthermore, finding that councils are more likely to be introduced where workers already earn high wages and have long tenure once again highlights the importance of accounting for selectivity of works council coverage and unobserved heterogeneity when studying the effects of works councils.

As more data become available, it will be interesting to take a look at the further developments at plants after works council introductions. Tracking those plants can yield insights in the ways workers actually use power and whether this changes as councils mature. For instance, power that is initially seized without such intentions may later on still be used to increase wages at the expense of the owners. Following these plants over time promises more detailed insights into such processes than cross-sectional analyses, such as Jirjahn et al. (2011). What is more, we can learn about management's responses to an increase in the workers' influence by looking at plants that introduce a council. This may improve our understanding of potential effects of changes in industrial relations systems and thus provide valuable guidance for policy makers.

\section{Acknowledgements}

I am indebted to Claus Schnabel for his guidance throughout this project. I am grateful to Thomas Zwick for insightful conversations and advice. I also thank Tobias Brändle, Boris Hirsch, Steffen Müller, Robin Naylor and two anonymous referees for helpful comments. I benefited from comments received at the 14th BGPE Workshop, the IAB Establishment Panel Survey User Conference, the 2013 Workshop on Personnel Economics and Economics of Education of the University of Zurich and the 2013 Annual Conference of the Scottish Economic Society. Any remaining mistakes are my responsibility, of course. I visited University of Warwick during the work on this article, and I am thankful for their hospitality.

\section{Declaration of Conflicting Interests}

The author(s) declared no potential conflicts of interest with respect to the research, authorship, and/or publication of this article. 


\section{Funding}

Writing of this article has been partially supported by the Bavarian Graduate Programme in Economics.

\section{Notes}

1. For a more international perspective and a comparison of the effects of different arrangements of workplace representation in Europe on firm performance, see Van den Berg et al. (2013).

2. Wilkesmann et al.'s (2011) survey of workers in plants without a works council suggests that management is sometimes opposed to council introductions, though this opposition appears not to be the main cause for the absence of a council since only $7 \%$ of the respondents report that management interfered with an introduction. Furthermore, a survey by Schlömer-Laufen and Kay (2012), again conducted among workers in plants without a council, shows that opposition of the management is no major reason for not introducing a works council.

3. Addison (2009) and Jirjahn (2011) survey the literature on works councils more broadly and emphasize the effects of councils on outcomes like productivity and wages.

4. Opening clauses can enable plants to reduce wages below the level specified in a binding collective agreement under certain circumstances. Such clauses would undermine this line of reasoning if workers introduce councils to prevent wage cuts via opening clauses. Kohaut and Schnabel (2007) report that opening clauses are rarely used to lower wages and that opening clauses can only be applied with the works council's consent. Hence, having no works council would prevent the use of such clauses and such clauses should not be of concern in this setting. While Kohaut and Schnabel (2007) do not find a positive link between the presence of a works council and the application of opening clauses empirically, Brändle and Heinbach (2013) provide evidence for a positive relationship between works council existence and the existence of opening clauses, management's knowledge of the clauses as well as the application of opening clauses.

5. Workers' wages are censored from above at the social security contribution ceiling. Since I use only information on the median wage in plants, this censoring is only a problem when the median worker in a plant earns a wage above the ceiling. This is extremely rare (fewer than $0.3 \%$ of the observations in the sample) and I hence ignore the censoring of wages.

6. To be more precise, the link is $F(\cdot)=1-\exp (-\exp (\cdot))$. Unlike in the probit or logit case, this link is asymmetric and therefore better suited for rare events. However, the results do not hinge on this link function as probit models give similar results.

7. As an alternative way to control for regional differences, I also included state dummies. The results in Appendix Tables A1 and A2 show that this does not change the results. Further, the state dummies are jointly insignificant with $p$-values between 0.252 and 0.353 .

8. Note that I do not include the means of all variables for two reasons. First, some plant characteristics vary only very little, e.g. whether a plant is in foreign ownership or its legal form. Second, variation in some of the other variables seems to be quite noisy, e.g. see Ellguth and Kohaut (2011), who give account of an editing procedure for plants that repeatedly change their reported collective bargaining status. Both problems make a precise estimation of the respective coefficients impossible when controlling for the plant-level average as this eliminates most of the meaningful variation.

9. For the sake of brevity, the coefficients $\hat{\xi}$ are not reported in the tables, but are available upon request.

10. As one would expect from this the results regarding wages are also similar to those reported when dropping workers' tenure and the unemployment rate from the regression. 
11. Regarding employer-provided training, the data contain only information on (1) types of training offered and (2) total training over all types. Further, this information is not available for all years. To measure plant-specific training, I hence use a dummy taking the value of 1 if the plant reported any plant-specific training activities in the last survey that included this item. To measure workers' labour market situation by their occupations, I calculate unemployment rates specific to each plant's workforce from the workforce composition by 2-digit occupation and (un)employment data at the same level.

12. The various groups of plants can easily be identified in the data. Direct information is included on the expected employment growth in the next year and expected employment in five years' time (only asked in every other year) as well as on the plants' profit situation in the previous year and the expected change in the plants' business volume. Plants covered by a collective agreement are furthermore asked whether they pay wages above the level specified in these.

\section{References}

Addison JT (2009) The Economics of Codetermination: Lessons from the German Experience. New York: Palgrave Macmillan.

Addison JT, Bellmann L, Schnabel C and Wagner J (2003) German works councils old and new: Incidence, coverage and determinants. Schmollers Jahrbuch 123(3): 339-358.

Addison JT, Bryson A, Teixeira P, Pahnke A and Bellmann L. (2013) The extent of collective bargaining and workplace representation: Transitions between states and their determinants. A comparative analysis of Germany and Great Britain. Scottish Journal of Political Economy 60(2): 182-209.

Addison JT, Schnabel C and Wagner J (2001) Works councils in Germany: Their effects on establishment performance. Oxford Economic Papers 53: 659-694.

Addison JT, Teixeira P and Zwick T (2010) German works councils and the anatomy of wages. Industrial and Labor Relations Review 63(2): 247-270.

Alda H, Bender S and Gartner H (2005) The linked employer-employee dataset created from the IAB Establishment Panel and the process-produced data of the IAB (LIAB). Schmollers Jahrbuch 125(2): 327-336.

Beckmann M, Föhr S and Kräkel M (2010) Rent seeking, employment security, and works councils: Theory and evidence for Germany. Schmalenbach Business Review 62(1): 2-40.

Blossfeld HP (1985) Bildungsexpansion und Berufschancen: Empirische Analysen zur Lage der Berufsanfänger in der Bundesrepublik. Frankfurt am Main: Campus Verlag.

Boockmann B and Steffes S (2010) Workers, firms or institutions: What determines job duration for male employees in Germany? Industrial and Labor Relations Review 64(1): 109-127.

Brändle T and Heinbach WD (2013) Opening clauses in collective bargaining agreements: More flexibility to save jobs? Review of Economics 64(2): 159-192.

Cameron AC and Trivedi PK (2005) Microeconometrics: Methods and Applications. New York: Cambridge University Press.

Dilger A (2003) Payment schemes, returns and works councils. Schmollers Jahrbuch 123(3): 383-395.

Ellguth P and Kohaut S (2011) Tarifbindung und betriebliche Interessenvertretung - aktuelle Ergebnisse aus dem IAB-Betriebspanel 2010. WSI-Mitteilungen 64(5): 242-247.

Farber HS (1999) Mobility and stability: The dynamics of job change in labor markets. In: Ashenfelter OC and Card D (eds) Handbook of Labor Economics, Vol. 3B. Amsterdam: North-Holland, pp. 2439-2483.

Freeman RB and Lazear EP (1995) An economic analysis of works councils. In: Rogers J and Streeck W (eds) Works Councils: Consultation, Representation, and Cooperation in Industrial Relations. Chicago: University of Chicago Press, pp. 27-50. 
Freeman RB and Medoff JL (1979) The two faces of unionism. Public Interest 57: 69-93.

Freeman RB and Medoff JL (1984) What Do Unions Do? New York: Basic Books.

Gralla R and Kraft K (2012) Separating introduction effects from selectivity effects: The differences in employment patterns of co-determined firms. Discussion Paper No. 7022, Institute for the Study of Labour, Bonn, Germany.

Grund C and Schmitt A (2013) Works councils, wages and job satisfaction. Applied Economics 45(3): 299-310.

Hirsch B and Schnabel C (2012) Women move differently: Job separations and gender. Journal of Labor Research 33(4): 417-442.

Hirsch B, Schank T and Schnabel C (2010) Works councils and separations: Voice, monopoly, and insurance effects. Industrial Relations 49(4): 566-592.

Hirschman AO (1970) Exit, Voice, and Loyalty: Responses to Decline in Firms, Organizations, and States. Cambridge, MA: Harvard University Press.

Hübler O and Jirjahn U (2003) Works councils and collective bargaining in Germany: The impact on productivity and wages. Scottish Journal of Political Economy 50(4): 471-491.

Jirjahn U (2009) The introduction of works councils in German establishments: Rent seeking or rent protection? British Journal of Industrial Relations 47(3): 521-545.

Jirjhan U (2010) Works councils and employment growth in German establishments. Cambridge Journal of Economics 34(3): 475-500.

Jirjahn U (2011) Ökonomische Wirkungen der Mitbestimmung in Deutschland: Ein Update. Schmollers Jahrbuch 131(1): 3-57.

Jirjahn U (2014) Works councils and collective bargaining in Germany: A simple but crucial theoretical extension. Research Papers in Economics No. 13/14, University of Trier, Germany.

Jirjahn U and Mohrenweiser J (2013) Active owners and the failure of newly adopted works councils. Discussion Paper No. 13-080, Centre for European Economic Research, Mannheim, Germany.

Jirjahn U, Mohrenweiser J and Backes-Gellner U (2011) Works councils and learning: On the dynamic dimension of codetermination. Kyklos 64(3): 427-447.

Jung S and Schnabel C (2011) Paying more than necessary? The wage cushion in Germany. Labour 25(2): 182-197.

Kohaut S and Schnabel C (2007) Tarifliche Öffnungsklauseln - Verbreitung, Inanspruchnahme und Bedeutung. Sozialer Fortschritt 56(2): 33-40.

Kraft K and Lang J (2008) The causes and consequences of adopting a works council. Jahrbücher für Nationalökonomie und Statistik 228(5\&6): 512-532.

Kriechel B, Mühlemann S, Pfeifer H and Schuette M (2014) Works councils, collective bargaining and apprenticeship training. Industrial Relations 53(2): 199-222.

Mohrenweiser J, Marginson P and Backes-Gellner U (2012) What triggers the establishment of works councils? Economic and Industrial Democracy 33(2): 295-316.

Mueller S (2011) Works councils and firm profits revisited. British Journal of Industrial Relations 49(2): 27-43.

Mueller S (2012) Works councils and establishment productivity. Industrial and Labor Relations Review 65(4): 880-898.

Mueller S and Stegmaier J (2014) The dynamic effects of works councils on labor productivity. First evidence from panel data. Discussion Paper No. 78, LASER, Erlangen, Germany.

Mundlak Y (1978) On the pooling of time series and cross section data. Econometrica 46(1): 66-85.

Pfeifer C (2011a) Works councils, union bargaining and quits in German firms. Economic and Industrial Democracy 32(2): 243-260. 
Pfeifer C (2011b) The heterogeneous economic consequences of works council relations. Schmollers Jahrbuch 131(1): 59-71.

Schlömer-Laufen N and Kay R (2012) Betriebsratsgründungen in kleinen und mittleren Unternehmen: Die Rolle der Belegschaften. Berlin: Edition Sigma.

Topel R (1991) Specific capital, mobility, and wages: Wages rise with job seniority. Journal of Political Economy 99(1): 145-176.

Van den Berg A, Grift Y, Van Witteloostuijn A, Boone C and Van der Brempt O (2013) The effect of employee workplace representation on firm performance: A cross-country comparison within Europe. Tjalling C. Koopmans Discussion Paper Series 13-05, Utrecht University, the Netherlands.

Wigboldus JE, Grift Y, Van den Berg A and Looise JK (2014) The economic effects of works councils: Channels and conditions. Using secondary data to test a new theoretical model. Economic and Industrial Democracy. Epub ahead of print 31 October 2014. DOI: 0143831X14551998.

Wilkesmann U, Wilkesmann M, Virgillito A and Bröcker T (2011) Erwartungen an Interessenvertretungen: Analysen anhand repräsentativer Umfragedaten. Berlin: Edition Sigma.

Wooldridge JM (2010) Econometric Analysis of Cross Section and Panel Data, 2nd edn. Cambridge, MA: MIT Press.

\section{Author biography}

Michael Oberfichtner is a researcher at Friedrich-Alexander-University of Erlangen-Nürnberg and at the Institute for Employment Research (IAB) Nürnberg, Germany. His main research interests include industrial relations and the link between product market conditions and labour market outcomes. One recent publication from the latter field is (joint with B Hirsch and C Schnabel) 'The levelling effect of product market competition on gender wage discrimination', IZA Journal of Labor Economics 3 (2014). 


\section{Appendix: Results using a stronger regional disaggregation}

Table Al. Average partial effects on the probability of a works council introduction.

\begin{tabular}{|c|c|c|c|c|}
\hline \multirow[t]{2}{*}{ Explanatory variables } & \multicolumn{2}{|c|}{$\begin{array}{l}\text { Pooled maximum } \\
\text { likelihood }\end{array}$} & \multicolumn{2}{|c|}{$\begin{array}{l}\text { Correlated random } \\
\text { effects }\end{array}$} \\
\hline & APE & SE & APE & SE \\
\hline Median tenure & $0.0005^{* * *}$ & 0.0002 & $0.0014 * * *$ & 0.0003 \\
\hline Unemployment rate & -0.0001 & 0.0002 & 0.0001 & 0.0004 \\
\hline Collective bargaining at the sector level (d) & $0.0069 * * *$ & 0.0015 & $0.0069 * * *$ & 0.0015 \\
\hline Collective bargaining at the firm level (d) & $0.0096 * * *$ & 0.0040 & $0.0100 * * *$ & 0.0041 \\
\hline Plant with limited liability (d) & $0.0076 * * *$ & 0.0011 & $0.0073 * * *$ & 0.0011 \\
\hline Branch plant (d) & $0.0184 * * *$ & 0.0029 & $0.0181 * * *$ & 0.0030 \\
\hline Plant in foreign ownership (d) & 0.0031 & 0.0026 & 0.0031 & 0.0026 \\
\hline Plant located in rural area (d) & 0.0001 & 0.0013 & 0.0003 & 0.0013 \\
\hline Plant with $21-100$ workers (d) & $0.0046 * * *$ & 0.0010 & $0.0050 * * *$ & 0.0011 \\
\hline Plant with $10 \mathrm{I}-199$ workers (d) & $0.0143 * * *$ & 0.0035 & $0.0148 * * *$ & 0.0036 \\
\hline Plant with 200 or more workers (d) & $0.0346 * * *$ & 0.0066 & $0.0351 * * *$ & 0.0069 \\
\hline Organizational shock (d) & $0.0054 * *$ & 0.0027 & $0.0053^{* *}$ & 0.0027 \\
\hline $\begin{array}{l}\text { Good profit situation (previous business } \\
\text { year, d) }\end{array}$ & 0.0010 & 0.0011 & $0.0023^{*}$ & 0.0012 \\
\hline Relative employment growth & $0.0008 * *$ & 0.0004 & 0.0006 & 0.0008 \\
\hline Median age & 0.0000 & 0.0001 & $0.0004 *$ & 0.0002 \\
\hline Share of part-time workers & $0.0053 * *$ & 0.0026 & $0.0107 *$ & 0.0056 \\
\hline Share of female workers & -0.0009 & 0.0029 & 0.0064 & 0.0082 \\
\hline Share of apprentices & -0.0103 & 0.0075 & $0.0328 * *$ & 0.0149 \\
\hline Share of highly qualified workers & $0.0099 * *$ & 0.0040 & $0.0266 * * *$ & 0.0094 \\
\hline Share of qualified workers & 0.0039 & 0.0032 & $0.0142 * *$ & 0.0060 \\
\hline Share of workers in manual occupations & 0.0005 & 0.0027 & $0.0201 *$ & 0.0110 \\
\hline Share of workers in business occupations & 0.0026 & 0.0028 & -0.0014 & 0.0063 \\
\hline $\begin{array}{l}p \text {-value for } \mathrm{H} 0 \text { that all state dummies are } \\
\text { zero }\end{array}$ & 0.2522 & & 0.2521 & \\
\hline Observations & 29,190 & & 29,190 & \\
\hline Works council introductions & 237 & & 237 & \\
\hline
\end{tabular}

Notes: Replication of Table 3 including state dummies instead of one dummy for plants in East Germany. 
Table A2. Average partial effects on the probability of a works council introduction, controlling for the wage level.

\begin{tabular}{|c|c|c|c|c|}
\hline \multirow[t]{2}{*}{ Explanatory variables } & \multicolumn{2}{|c|}{$\begin{array}{l}\text { Correlated random } \\
\text { effects w/o average } \\
\text { wage }\end{array}$} & \multicolumn{2}{|c|}{$\begin{array}{l}\text { Correlated random } \\
\text { effects with average } \\
\text { wage }\end{array}$} \\
\hline & APE & SE & APE & SE \\
\hline Log(median wage) & $0.0115 * * *$ & 0.0022 & -0.0039 & 0.0037 \\
\hline Average log(median wage) & & & $0.0166 * * *$ & 0.0044 \\
\hline Median tenure & $0.0014 * * *$ & 0.0003 & $0.0014 * * *$ & 0.0003 \\
\hline Unemployment rate & 0.0003 & 0.0004 & 0.0003 & 0.0005 \\
\hline $\begin{array}{l}\text { Collective bargaining at the sector } \\
\text { level (d) }\end{array}$ & $0.0069 * * *$ & 0.0015 & $0.0068 * * *$ & 0.0015 \\
\hline $\begin{array}{l}\text { Collective bargaining at the firm } \\
\text { level (d) }\end{array}$ & $0.0099 * * *$ & 0.0040 & $0.0099 * * *$ & 0.0040 \\
\hline Plant with limited liability (d) & $0.0069 * * *$ & 0.0011 & $0.0069 * * *$ & 0.0011 \\
\hline Branch plant (d) & $0.0159 * * *$ & 0.0027 & $0.0156 * * *$ & 0.0027 \\
\hline Plant in foreign ownership (d) & 0.0008 & 0.0023 & 0.0007 & 0.0023 \\
\hline Plant located in rural area (d) & 0.0005 & 0.0013 & 0.0006 & 0.0013 \\
\hline Plant with $21-100$ workers (d) & $0.0049 * * *$ & 0.0011 & $0.0049 * * *$ & 0.0011 \\
\hline Plant with $101-199$ workers (d) & $0.0142 * * *$ & 0.0035 & $0.014 \mid * * *$ & 0.0035 \\
\hline Plant with 200 or more workers (d) & $0.0330 * * *$ & 0.0064 & $0.0325 * * *$ & 0.0063 \\
\hline Organizational shock (d) & $0.0055^{* *}$ & 0.0027 & $0.0055^{* *}$ & 0.0027 \\
\hline $\begin{array}{l}\text { Good profit situation (previous } \\
\text { business year, } d \text { ) }\end{array}$ & $0.0024^{*}$ & 0.0012 & $0.0023 *$ & 0.0012 \\
\hline Relative employment growth & 0.0006 & 0.0007 & 0.0005 & 0.0006 \\
\hline Median age & 0.0004 & 0.0002 & 0.0003 & 0.0002 \\
\hline Share of part-time workers & 0.0079 & 0.0062 & $0.0127 * *$ & 0.0062 \\
\hline Share of female workers & 0.0073 & 0.0085 & 0.0054 & 0.0086 \\
\hline Share of apprentices & $0.0316^{* *}$ & 0.0154 & $0.0335^{* *}$ & 0.0153 \\
\hline Share of highly qualified workers & $0.0259 * * *$ & 0.0101 & $0.0281 * * *$ & 0.0103 \\
\hline Share of qualified workers & $0.0144^{* *}$ & 0.0063 & $0.0152 * *$ & 0.0064 \\
\hline $\begin{array}{l}\text { Share of workers in manual } \\
\text { occupations }\end{array}$ & 0.0188 & 0.0116 & $0.0207 *$ & 0.0114 \\
\hline $\begin{array}{l}\text { Share of workers in business } \\
\text { occupations }\end{array}$ & -0.0049 & 0.0070 & 0.0002 & 0.0069 \\
\hline $\begin{array}{l}p \text {-value for } \mathrm{H} 0 \text { that all state } \\
\text { dummies are zero }\end{array}$ & 0.3532 & & 0.3287 & \\
\hline Observations & 29,190 & & 29,190 & \\
\hline Works council introductions & 237 & & 237 & \\
\hline
\end{tabular}

Notes: Replication of Table 4 including state dummies instead of one dummy for plants in East Germany. 